\title{
Antibiosis and Dark-Pigments Secretion by the Phytopathogenic and Environmental Fungal Species after Interaction in vitro with a Bacillus subtilis Isolate
}

\author{
Alexandre Paulo Machado ${ }^{1,3^{*}}$, Viviane Karolina Vivi ${ }^{1}$, José Roberto Tavares $^{2}$, Frederico \\ José Gueiros Filho ${ }^{2}$ and Olga Fischman ${ }^{3}$ \\ ${ }^{I}$ Departamento de Ciências Básicas em Saúde; Faculdade de Ciências Médicas; Universidade Federal de Mato \\ Grosso; Av Fernando Corrêa s/n; Cuiabá - MT - Brasil. ${ }^{2}$ Departamento de Bioquímica; Instituto de Química; \\ Universidade de São Paulo; Av Prof. Lineu Prestes, 748; São Paulo - SP - Brasil. ${ }^{3}$ Departamento de Microbiologia, \\ Imunologia e Parasitologia; Universidade Federal de São Paulo; Rua Botucatu, 862; São Paulo - SP - Brasil
}

\begin{abstract}
In this work, different reactions in vitro between an environmental bacterial isolate and fungal species were related. The Gram-positive bacteria had terminal and subterminal endospores, presented metabolic characteristics of mesophilic and acidophilic growth, halotolerance, positive to nitrate reduction and enzyme production, as caseinase and catalase. The analysis of partial sequences containing 400 to 700 bases of the 16S ribosomal RNA gene showed identity with the genus Bacillus. However, its identity as B. subtilis was confirmed after analyses of the rpoB, gyrA, and $16 S$ rRNA near-full-length sequences. Strong inhibitory activity of environmental microorganisms, such as Penicillium sp, Aspergillus flavus, A. niger, and phytopathogens, such as Colletotrichum sp, Alternaria alternata, Fusarium solani and F. oxysporum f.sp vasinfectum, was shown on co-cultures with B. subtilis strain, particularly on Sabouraud dextrose agar (SDA) and DNase media. Red and red-ochre color pigments, probably phaeomelanins, were secreted by A. alternata and A. niger respectively after seven days of co-culture.
\end{abstract}

Key-words: Bacillus subtilis, phytopathogenic fungi, environmental fungi, microbial interaction

\section{INTRODUCTION}

The genus Bacillus is widely diversified and spread throughout the world from many sources such as air, soil, water, and gastrointestinal tracts of animals and humans (Guo et al., 2006, Earl et al., 2007, Rintala et al., 2008). Many species are extremophyles, or tolerant to more strict conditions such as high alkalinity, acidity, salinity or temperature (Niehaus et al., 1999, Horikoshi, 2008). Endospore production by such bacilli may be resistant to desiccation, heat, UV light and organic solvents (Nicholson et al., 2000). In general, these microorganisms are saprobes and rarely pathogenic.

Bacillus spp have powerful biotechnological applications such as natural biocontrol of pests in agriculture, production of insecticides, antibiotics and enzymes and probiotics for human and animal microbiota regulation (Niehaus et al., 1999, Luna et al., 2005, Monteiro et al., 2005, Souza et al., 2005, Guo et al., 2006, Whipps, 2001).

Antibiosis against the phytopathogenic microorganisms has been frequently associated with secondary metabolites (Romero et al., 2007, Pryor et al., 2007, Keel and Défago, 1997).

\footnotetext{
*Author for correspondence: alepaulo@ hotmail.com
} 
Co-cultures of filamentous fungi and Bacillus spp can lead to increased bacteriocins production (Abee et al., 1995, Cornea et al., 2003). The synthesis of these inhibitory substances have been described by different species, such as Bacillus subtilis, $B$. cereus, $B$. polymixa, $B$. amyloliquefaciens, $B$. stearothermophilus, $B$. brevis, $B$. thuringiensis, $B$. megaterium, $B$. licheniformis and B. circulans (Abee et al., 1995, Whipps, 2001, Stein, 2005).

Many misclassifications have been found in the phylum Firmicutes (Wang et al., 2007). De Clerck et al. (2004) reported that the analysis of only the 16S rRNA gene was unsuitable for the species or sub-species identification of the genus Bacillus, particularly of the cereus and subtilis groups. Sequencing of other genes, such as gyrA and rpoB, was suggested to aid in molecular identification of the subtilis group because of the great homology among 16S rRNA sequences (Chun and Bae, 2000, Earl et al., 2007).

The aim of this work was to study different interactions in vitro of environmental and phytopathogenic fungi with a Gram-positive bacillus isolated from soil. This bacterial species was identified through their phenotypical profiles and molecular sequencing analyses.

\section{MATERIAL AND METHODS}

\section{Microorganisms}

Approximately $10 \mathrm{~g}$ of soil were randomly collected in the University Federal of Mato Grosso Campus, Cuiabá (Mato Grosso, Brazil). The samples were homogenized separately with 100 $\mathrm{mL}$ phosphate buffered saline (PBS, $\mathrm{pH}$ 7.2) in $200 \mathrm{~mL}$ glass beakers, filtered in a common paper filter, and decanted for two hours. Supernatants were diluted to concentrations of $1 / 10$ and $1 / 100$, plated on trypticase ${ }^{\mathrm{TM}}$ soy agar (TSA, Difco/BBL, $\mathrm{pH}$ 7.3), and incubated at $30^{\circ} \mathrm{C}$ for one week. Several fungi and bacterial colonies were observed in these cultures. However, only the bacteria that exhibited antifungical activity were selected for later studies against environmental fungi (Penicillum sp, Aspergillus flavus, A. niger) and phytopathogens (Alternaria alternata, Fusarium solani, F. oxysporum f.sp vasinfectum, Colletotrichum sp). All fungal species used in this study were previously cultivated on Sabouraud dextrose agar (SDA, Difco/BBL), supplemented with $80 \mathrm{mg} / \mathrm{L}$ gentamycin.

\section{Classical characterization}

The preliminary identification of the bacteria was performed by macroscopic analysis of colonies and microscopic morphology, including endospore position and Gram stain. Biochemical tests were performed for citrate utilization; nitrate reduction; growth on mannitol and growth in 6.5 and $10 \%$ $\mathrm{NaCl}$; production of $\mathrm{H}_{2} \mathrm{~S}$, indole, methyl red, Voges-Proskauer (VP); and hydrolysis of esculin (Foldes et al., 2000, Reva et al., 1995, Winn et al., 2006). Enzymatic tests were performed to detect the production of amylase, ornithinedecarboxylase, oxidase, catalase, urease, lecithinase, DNase, lipase, caseinase and haemolysins (Winn et al., 2006, Sanchez-Porro et al., 2003). The growth of the bacterial strain on TSA and tryptic soy broth (TSB, Difco), pH 7.3, and SDA, $\mathrm{pH} 5.6$, was observed at different temperatures $\left(4,20,25,37,42\right.$, and $\left.55^{\circ} \mathrm{C}\right)$ over intervals of 24 and $48 \mathrm{~h}$.

\section{Co-cultures}

Bacterial and fungal inocula were cultivated at a distance of 3 to $5 \mathrm{~cm}$ from each other on Petri plates containing TSA or SDA. Co-cultures were maintained at $28^{\circ} \mathrm{C}$ and were observed daily for one week. Antagonistic activity was verified by inhibition halo growth of fungal species (Cornea et al., 2003, Lisboa et al., 2006). Co-cultures of the bacterial and fungal species were also performed in DNase agar with $0.1 \mathrm{~g} / \mathrm{L}$ toluidine blue (Difco/BBL, pH 7.3), using Staphylococcus aureus ATCC 25923 as the positive control and Staphylococcus epidermidis ATCC 12228 as the negative control. DNase agar was used specifically for co-cultivation because previous observations showed that the zones with enzymatic activity in this medium coincided with a green fluorescent light ring around the bacterial colonies. Green fluorescent light was correlated with the zones of fungal inhibition in vitro in the co-cultures. Furthermore, the relationship between nucleic acid hydrolysis and microbial antagonism was also investigated. To verify whether the substances produced by the Bacillus sp reacted with dye used in the DNase medium, co-cultures were performed on SDA Petri-plates supplemented with $0.1 \mathrm{~g} / \mathrm{L}$ toluidine blue. 


\section{Extraction and purification of genomic DNA}

After $24 \mathrm{~h}$ growth at $30^{\circ} \mathrm{C}$ on TSA, the bacterial colonies were suspended in $400 \mu \mathrm{L}$ of lysis buffer containing $50 \mu \mathrm{L}$ of lysozyme and $25 \mu \mathrm{L}$ of RNase, yielding final concentrations of approximately $1 \mathrm{mg} /$ Eppendorf tube and 10 $\mu \mathrm{g} / \mathrm{mL}$, respectively. Eppendorf tubes were incubated at $37^{\circ} \mathrm{C}$ for $15 \mathrm{~min}$ with careful shaking. Then, $50 \mu \mathrm{L} 20 \%$ lauroylsarcosine (Sigma Aldrich) was added to the lysates, which were kept on ice for $5 \mathrm{~min}$ to obtain a translucent material. Approximately $500 \mu \mathrm{L}$ of phenol:chloroform (Sigma Aldrich) was added to the tubes. Genetic material was precipitated in 1 $\mathrm{mL}$ ethanol with $0.3 \mathrm{M} \mathrm{NaOAc}$ for $5 \mathrm{~min}$ at room temperature. The pellet was centrifuged and quickly washed with $70 \%$ ethanol and resuspended in $100 \mu \mathrm{L}$ TE buffer. Genomic preparations were quantified using a spectrophotometer at $260 \mathrm{~nm}$ and samples were kept at $-20^{\circ} \mathrm{C}$ until use.

\section{Amplification of $16 \mathrm{~S}$ rRNA, rpoB and gyrA genes}

The PCR-reactions were performed with the following universal primers: $16 \mathrm{~S}$ rRNA $(8 \mathrm{bF}, 5$ 'ACTGGGATCCACAGGAGTGCAAACGACG A-3'; 518f, 5'- CCAGCAGCCGCGGTAAT-3'; 1406r, 5'-ACGGGCGGTGTGTRC-3'; and 1512r, 5'- CTGAAGCTTACGGYTAGCTTGTTACGAC TT-3'), gyrA (gyrA-f, 5' -CAGTCAGGAAATGC GTACGTCCTT-3' and gyrA-r, 5'-CAAGGTAA TGCTCCAGGCATTGCT-3'), and rpoB (rpoB-f, 5'-AGGTCAACTAGTTCAGTATGGAC-3' and rpoB-r, 5'-AAGAACCGTAACCGGCAACTT-3') (De Clerck et al., 2004). Each $50 \mu \mathrm{L}$ PCR reaction mix contained $5 \mu \mathrm{L}$ Taq buffer $10 \mathrm{x}, 3 \mu \mathrm{L} \mathrm{MgCl}_{2}$ $25 \mathrm{mM}, 0.4 \mu \mathrm{L}$ dNTPs $25 \mathrm{mM}, \quad 0.5 \mu \mathrm{L}$ Taqpolymerase $5 \mathrm{U} / \mathrm{mL}$ (all reagents from Fermentas), $1.25 \mu \mathrm{L}$ primer $20 \mathrm{mM}, 50 \mathrm{ng}$ genomic DNA and $36.1 \mu \mathrm{L} \mathrm{H}_{2} \mathrm{O}$ milli-Q. A positive control reaction was directly performed from bacterial cells and PCR mix. The PCR reactions were performed in a BioRad thermal cycler (PTC 1148 MJ mini thermal cycler) using 35 cycles $\left(1 \mathrm{~min}\right.$ denaturing at $94^{\circ} \mathrm{C}, 1 \mathrm{~min}$ annealing at $48^{\circ} \mathrm{C}, 2 \mathrm{~min}$ extension at $72^{\circ} \mathrm{C}$, and finally a 9 min extension at $72^{\circ} \mathrm{C}$. The resulting amplicons were subjected to ultrapure $1 \%$ agarose gel electrophoresis (Invitrogen) using GeneRuler 1 kb DNA ladder (Life Sciences) as a molecular weight marker.

\section{Sequencing of 16S rRNA, rpoB, and gyrA genes and sequence analyses.}

Five PCR products from each amplified gene were extracted from agarose gel with QIAEX II Gel Extraction Kit (QIAGEN). Each $15 \mu \mathrm{L}$ PCR reaction contained $100 \mathrm{ng}$ purified DNA, $3 \mu \mathrm{L}$ sequencing buffer $5 \mathrm{X}, 2 \mu \mathrm{L}$ Big Dye, 10 pmol primers and $\mathrm{H}_{2} \mathrm{O}$. Gene sequences were determined on an ABI PRISM ${ }^{\circledR} 3100$ Genetic Analyzer (Applied Biosystems). The Bioedit program and ClustalW2 (www.ebi.ac.uk/Tools /clustalw2/index.html) were used to sequence the alignments. Partial sequences were blasted in the bank databases, such as GenBank (www.ncbi.nlm. nih.gov), EMBL (www-db.embl.de), RDP II (rdp.cme.msu.edu), DDBJ (http://blast.ddbj.nig. ac.jp/top-e.html).

\section{Nucleotide sequencing accession numbers}

Partial sequences of environmental Bacillus subtilis strain were deposited in GenBank under accession numbers FJ025759 (rpoB), FJ025758 (gyrA), FJ025757 (16S rRNA).

\section{RESULTS}

\section{Classical and molecular classification}

The Gram-positive bacteria presented terminal and subterminal endospores, growth at 4 to $40^{\circ} \mathrm{C}$, halotolerance and good growth on acid media (SDA, pH 5.6). The reactions were positive for methyl red, Voges-Proskauer, motility, mannitol growth, nitrate utilization, as well as production of catalase, oxidase, caseinase, ornithine decarboxylase. The reactions were negative for citrate utilization, esculin growth, as well as the production of amylase, urease, indole, lecithinase, lipase, hemolysins and gas. The 16S rRNA gene was amplified directly from the bacterial cells or genomic DNA using primers 8bf and 1512r. Fragments of approximately $1.5 \mathrm{~kb}$ were sequenced, and partial 5' and 3' sequences containing 400 to 700 bases were aligned and analyzed. These sequences demonstrated $100 \%$ identity to the Bacillus genus in all the bank databases. However, a crossed identity of ribosomal genes over $95 \%$ was detected among the species of $B$. amyloliquefaciens, B. velezensis and $B$. subtilis. Subsequently, the primer $518 \mathrm{f}$ was used to amplify the central region of $16 \mathrm{~S}$ gene. 
A near-full-length cDNA sequence of $16 \mathrm{~S}$ rRNA gene with approximately 1.437 nucleotides was produced after manual alignment of 3' and 5' sequences from the PCR-products generated with primers $8 \mathrm{bf}, 518 \mathrm{f}$ and $1512 \mathrm{r}$. Other genes, such as rpoB and gyrA, were analyzed to confirm $B$. subtilis.

\section{In vitro interactions}

Antibioses of Bacillus sp was observed in cocultures against all the fungal species, including environmental fungi such as Penicillum sp, A. flavus, A. niger (Fig. 1A), and phytopathogens such as A. alternata, F. solani, $F$. oxysporum f.sp vasinfectum and Colletotrichum sp. Antifungal activity was more pronounced on SDA medium, suggesting increased synthesis of inhibitory substances in acidic $\mathrm{pH}$. In many instances, a line of precipitation was observed in co-cultures plates near the bacterial colony (Fig. 1-B).

Green fluorescence was observed after exposure to ultraviolet light (UV), particularly in the inhibition zone. Inhibitory zones on DNase medium (Fig. 2) containing toluidine-blue dye were initially light pink in color and then became yellow, whereas inhibitory zones on SDA medium with the same dye did not exhibit this pigmentation.

The diffusion of reddish-brown and red pigments, which were most likely phaeomelanin, on agar plates by fungal colonies of $A$. niger (Fig. 3-A) and A. alternata (Fig. 3-B) were observed after one week of co-culture with $B$. subtilis.

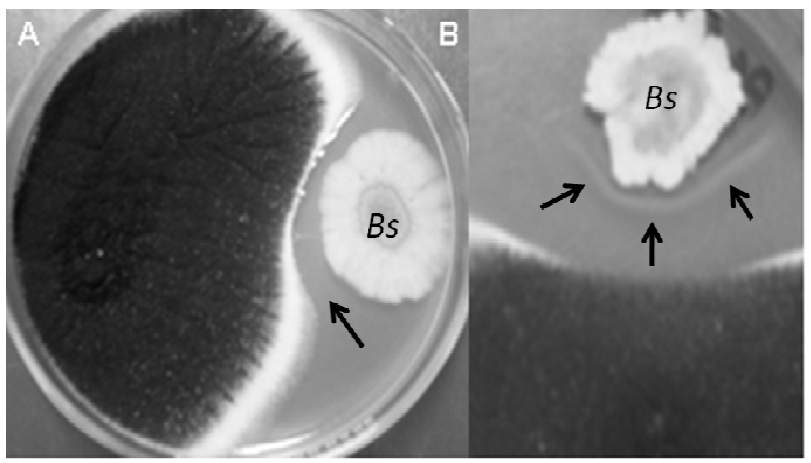

Figure 1 - Co-cultures between environmental strains of A. niger and B. subtilis (Bs). A) Inhibition of the fungal colony on SDA medium. B) Precipitation line formed near the bacterial colony.

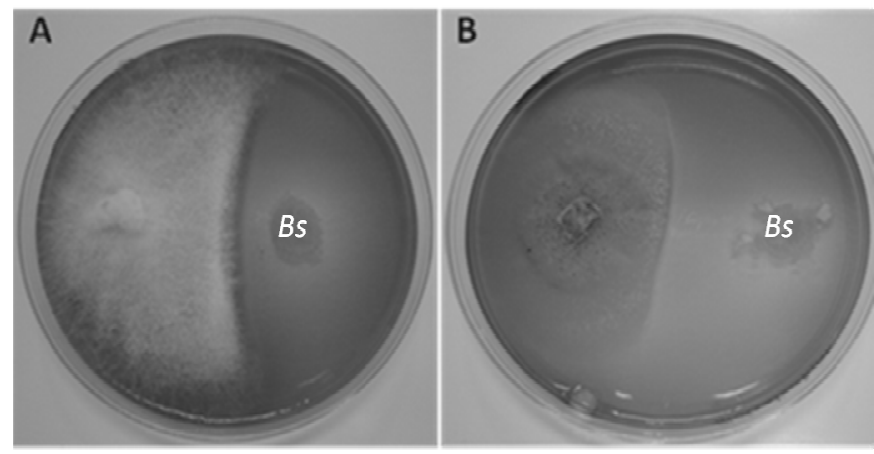

Figure 2 - Inhibitory growth of phytopathogens on DNase medium and zone linked to the antifungical activity of $B$. subtilis (Bs). A) F. oxysporum B) Colletotrichum sp. 

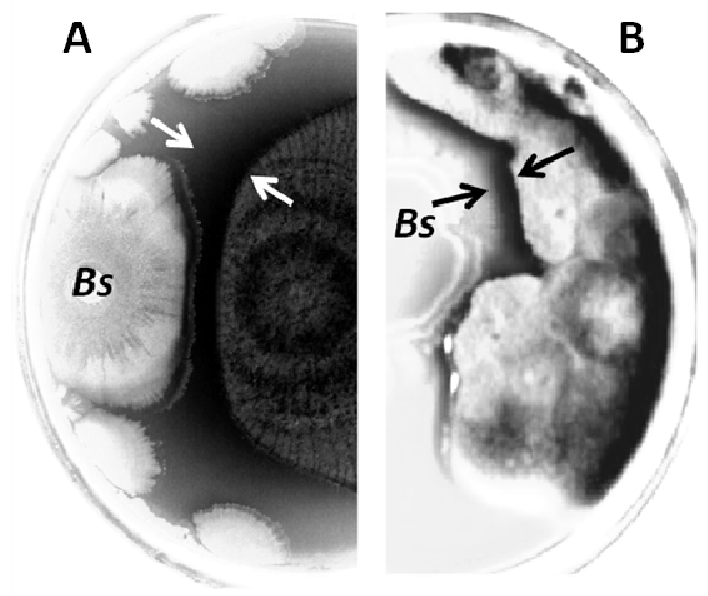

Figure 3 - Reddish-brown and red pigments secreted by Asp. niger (A) and A. alternata (B) after one week of co-culture with $B$. subtilis $(B s)$.

\section{DISCUSSION}

The identification of the Bacillus species is very difficult due to the high level of phenotypic variability, environmental diversity, and absence of suitable qualitative methods. For this reason, molecular analyses have been advantageous tools in characterization of the Bacillus spp. The phylum Firmicutes presents high homology in gene targets for phylogenetic characterization, such as 16S and 23S rRNA (Earl et al., 2007, Wang et al., 2007, Bavykin et al., 2004). Several conserved proteins related to cellular transcription and replication, such as RNA polymerases and DNA gyrases, respectively, can also be used in gene sequencing and phylogeny (Earl et al., 2007, Chun and Bae, 2000). Although the genetic heterogeneity of these proteins could be interesting for molecular characterization, a high intraspecific homology on subunits $\alpha$ or $\beta$ may be found across Bacillus groups making this a poor marker for differentiation of species and subspecies. The recovery of partial (over $400 \mathrm{bp}$ ) and near-full-length sequences have resulted in more accurate molecular identification than short sequences (near 200 bp) (Wang et al., 2007). Similarity among the aligned sequences should be $\geq 99 \%$ and the ideal is above $99.5 \%$. In this investigation, species-specific characterization after sequencing the $16 \mathrm{~S}$ rRNA gene was not successful. The identity of $100 \%$ with sequences of B. subtilis available in the database banks was observed only after crossing the near-full-sequence of $16 \mathrm{~S}$ rRNA gene and gene sequences of gyrA and rpoB.

Gram-positive bacilli are found in soil, acting as bioregulators, biocontrollers, and decompositors (Whipps, 2001, Araujo et al., 2005, Keel and Défago, 1997). Microbial interaction studies are very important in the discovery of antimicrobials, insecticides, and pro- and pre-biotics (Whipps, 2001, Guo et al., 2006, Stein, 2005). A variety of interactions, such as competition for nutrients or space, may be the cause of antagonistic reactions (Whipps, 1997, Keel and Défago, 1997). Antibiosis normally occurs via the release of substances that inhibit microbial growth (Whipps, 2001). The production of secondary metabolites by Bacillus spp, including antibiotics of lowmolecular-weight and natural cyclic-peptides, has been related to the inhibition of many organisms, including fungal species (Stein, 2005, Romero et al., 2007). The bacterium studied has shown good antifungal activity to environmental fungi and phytopathogens, particularly by antibiosis. As expected, B. subtilis that presented biocidal effectors against fungi has been utilized as a biocontroller of phytopathogenic fungi (Broggini et al., 2005). Precipitation lines between Bacillus and fungi colonies have been reported (Cornea et al., 2003). These are most likely due to compounds produced by the fungus whose spreading on agar may be associated with inhibitory substances produced by the Bacillus sp. 
Antagonism in vitro varies according to culture media, bacterial antagonist and fungal species (Walker et al., 1998). The $\mathrm{pH}$ might be crucial for inducing the enzyme production by Bacillus spp from an intestinal source. In present work, a more pronounced inhibition of fungi occurred in the acid medium (SDA, $\mathrm{pH}$ 5.6) compared to TSA ( $\mathrm{pH}$ 7.3). There are evidences that fungal inhibitory effects may be caused by enzymatic compounds (Cornea et al., 2003, Bizani and Brandelli, 2002, van der Wal et al., 1995). Active enzymes from Bacillus spp can damage the fungal cellular walls (Barbosa-Corona et al., 1999, Mavingui and Heulin, 1994). Bacterial exo-chitinases and glucanases may have an important antagonist role against fungi (Dijksterhuis et al., 1999, Keel and Défago, 1997). Many Gram-positive bacteria are good producers of DNase exoenzymes (SanchezPorro et al., 2003). In this study, a relationship between the antifungical activity and DNAhydrolysis zones was observed, suggesting that the secreted inhibitory factors might be involved with DNases. However, future studies are needed to investigate this hypothesis.

In many instances, microbial resistance to hostile environment is directly associated with dark pigmented polymers (Henson et al., 1999, Jacobson, 2000). Melanized cells are more resistant to hydrolytic enzymes, oxidative radicals, high temperatures, antifungals, and host defenses (Nosanchuck and Casadevall, 2003, Henson et al., 1999). In this work, a striking secretion of melanin by melanogenic fungi after co-culture with $B$. subtilis was observed in agar plates, showing that fungi under stressful growth conditions could produce pigments that might give more protection against the bacterial substances or could result the melanin pathway stimulation by secondary metabolites.

Biocontrollers have been proposed as safe methods due to their natural effects against the phytopathogens, low operational cost, ease of growing, high resistance to environmental conditions, stability during the industrial process, and non-toxicity to life (Elad, 2003, Pryor et al., 2007, Whipps, 1997). The interactions of Bacillus spp with the plants and soils have been linked to increases in vegetable biomass, elimination of pathogenic flora and more efficient fixation of nitrogen compounds (Whipps, 2001, Keel and Défago, 1997). These microorganisms may, thus, act as "phyto-probiotics". Regional utilization of biocontrols may be more attractive and ecologically suitable than other available alternatives largely used in the local agriculture pest control, such as chemical pesticides.

In this work, a natural antimicrobial action against environmental and phytopathogenic fungi was detected from an environmental bacterium isolate, indicating that this microorganism had the potential for biotechnological application as a biocontrol agent. However, more experimental assays would be necessary because the fungal induction of melanogenesis process could be a factor related to increased resistance and virulence of many species.

\section{ACKNOWLEDMENTS}

This work received the financial support of $\mathrm{CNPq}$ and FAPEMAT project number $\mathrm{N}^{\circ}$. 002.138/2007.

\section{ABBREVIATIONS}

SDA = Sabouraud dextrose agar, $\mathrm{SDB}=$ Sabouraud dextrose broth, PBS $=$ phosphate buffered saline, PCR $=$ Polymerase Chain Reaction, $\mathrm{rpoB}=\mathrm{RNA}$ polymerase subunit $\mathrm{B}$, gyrA = DNA gyrase subunit A, rRNA = ribosomal RNA.

\section{RESUMO}

Na presente investigação, nosso objetivo principal foi relatar diferentes interações in vitro de um isolado bacteriano ambiental com espécies fúngicas. Através da identificação clássica, nós verificamos que o bacilo ambiental apresentava endósporos terminais e subterminais, características metabólicas de mesofilia, acidofilia, halotolerância, redução de nitrato e produção de enzimas, como caseinase e catalase. Análise de sequiências parciais do gene 16S RNAr contendo de 400 a 700 bases revelou identidade com gênero Bacillus. No entanto, a espécie Bacillus subtilis foi confirmada somente depois da análise de seqüências dos genes rpoB, gyrA, and 16S RNAr. Intensa atividade inibitória aos fungos ambientais, como Penicillium sp, Aspergillus flavus, A. niger, 
e fitopatogênicos, como Colletotrichum sp, Alternaria alternata, Fusarium solani e $F$. oxysporum f.sp vasinfectum, foi observada em coculturas com a cepa bacteriana (B. subtilis), particularmente em ágar Sabouraud dextrose e ágar DNase. Pigmentos de cor avermelhada e vermelho-amarronzado, provavelmente feomelaninas, foram secretados respectivamente por colônias de A. alternata e A. niger depois de sete dias de co-cultivo.

\section{REFERENCES}

Abee, T., Krockel, L. and Hill, C. (1995), Bacteriocins: modes of action and potentials in food preservation and control of food poisoning. Int. J. Food Microbiol., 28, 169-85.

Araujo, F. F., Henning, A. and Hungria, M. (2005), Phytohormones and antibiotics produced by Bacillus subtilis and their effects on seed pathogenic fungi and on soybean root development. World J. Microbiol. Biotechnol., 21, 1639-1645.

Arras, G. and Arru, A. (1997), Mechanism of action of some microbial antagonists against fungal pathogens. Ann. Microbiol. Enzimol., 47, 97-120.

Barbosa-Corona, J. E., Contreras, J. C., VelazquezRobledo, R., Bautista-Justo, M., Gomez, R. M., CruzCamarillo, R. and Ibarra, J. E. (1999), Selection of chitinolityc strains of Bacillus thuringiensis. Biotechnol. Lett., 21, 1125-1129.

Bavykin, S. G., Lysov, Y. P., Zakhariev, V., Kelly, J. J., Jackman, J., Stahl, D. A. and Cherni, A. (2004), Use of $16 \mathrm{~S}$ rRNA, 23S rRNA, and gyrB gene sequence analysis to determine phylogenetic relationships of Bacillus cereus group microorganisms. J. Clin. Microbiol., 42, 3711-30.

Bizani, D. and Brandelli, A. (2002), Characterization of a bacteriocin produced by a newly isolated Bacillus sp. Strain 8 A. J. Appl. Microbiol., 93, 512-9.

Broggini, G., Duffy, B., Holliger, E., Schärer, H., Gessler, C. and Patocchi, A. (2005), Detection of the fire blight biocontrol agent Bacillus subtilis BD170 (Biopro®) in a Swiss apple orchard. Eur. J. Plant Pathol., 111, 93-100.

Chun, J. and Bae, K. S. (2000), Phylogenetic analysis of Bacillus subtilis and related taxa based on partial gyrA gene sequences. Antonie Van Leeuwenhoek, 78, 123-7.

Cornea, C. P., Grebenisan, I., Mateescu, R., Vamanu, E. and Campeanu, G. (2003), Isolation and Characterization of New Bacillus spp. Strains-Useful as Biocontrol Agents of Plant Pathogens. Rouman. Biotechnol. Lett., 8, 1115-1122.
De Clerck, E., Vanhoutte, T., Hebb, T., Geerinck, J., Devos, J. and De Vos, P. (2004), Isolation, characterization, and identification of bacterial contaminants in semifinal gelatin extracts. Appl. Environ. Microbiol., 70, 3664-72.

Dijksterhuis, J., Sanders, M., Gorris, L. G. and Smid, E. J. (1999), Antibiosis plays a role in the context of direct interaction during antagonism of Paenibacillus polymyxa towards Fusarium oxysporum. Appl. Environ. Microbiol., 86, 13-21.

Earl, A. M., Losick, R. and Kolter, R. (2007), Bacillus subtilis genome diversity. J. Bacteriol., 189, 1163-70.

Elad, Y. (2003), Biocontrol of foliar pathogens: mechanisms and application. Comm. Agricult. Appl. Biol. Sci., 68, 17-24.

Foldes, T., Banhegyi, I., Herpai, Z., Varga, L. and Szigeti, J. (2000), Isolation of Bacillus strains from the rhizosphere of cereals and in vitro screening for antagonism against phytopathogenic, food-borne pathogenic and spoilage micro-organisms. Appl. Environ. Microbiol., 89, 840-6.

Guo, X., Li, D., Lu, W., Piao, X. and Chen, X. (2006), Screening of Bacillus strains as potential probiotics and subsequent confirmation of the in vivo effectiveness of Bacillus subtilis MA139 in pigs. Antonie Van Leeuwenhoek, 90, 139-46.

Henson, J. M., Butler, M. J. and Day, A. W. (1999), The dark side of the mycelium: Melanins of Phytopathogenic Fungi. Annu. Rev. Phytopathol., 37, 447-471.

Horikoshi, K. (2008), Past, present and future of extremophiles. Extremophiles, 12, 1-2.

Jacobson, E. S. (2000), Pathogenic roles for fungal melanins. Clin. Microbiol. Rev., 13, 708-17.

Keel, C., and Défago, G. (1997), Interactions between beneficial soil bacteria and root pathogens: mechanisms and ecological impact, pp. 27-46. In A. C. Gange and V. K. Brown (eds.), Multitrophic Interactions in Terrestrial Systems. Blackwell Science, London.

Luna, C. L., Lopes, C. E., Massarani, G. (2005). Recovery of Bacillus sphaericus spores by flocculation/sedimentation and flotation. Braz. arch. biol. technol., 48, 61-70.

Mavingui, P. and Heulin, T. (1994), In vitro chitinase and antifungal activity of a soil, rhizosphere and rhizoplane population of Bacillus polymyxa. Soil. Biol. Biochem., 26, 801-803.

Monteiro, L., Mariano, R. L. R., Souto-Maior, A. M. (2005). Antagonism of Bacillus spp. against Xanthomonas campestris pv. campestris. Braz. arch. biol. technol., 48, 23-29.

Nicholson, W. L., Munakata, N., Horneck, G., Melosh, H. J. and Setlow, P. (2000), Resistance of Bacillus endospores to extreme terrestrial and extraterrestrial environments. Microbiol. Mol. Biol. Rev., 64, 548-72. 
Niehaus, F., Bertoldo, C., Kahler, M. and Antranikian, G. (1999), Extremophiles as a source of novel enzymes for industrial application. Appl. Microbiol. Biotechnol., 51, 711-29.

Nosanchuck, J. D. and Casadevall, A. (2003), The contribution of melanin to microbial pathogenesis. Cell. Microbiol., 5, 203-23.

Pryor, S. W., Siebert, K. J., Gibson, D. M., Gossett, J. M. and Walker, L. P. (2007), Modeling production of antifungal compounds and their role in biocontrol product inhibitory activity. J. Agric. Food. Chem., 55, 9530-6.

Reva, O. N., Vyunitskaya, V. A., Reznik, S. R., Kozachko, I. A. and Smirnov, V. V. (1995), Antibiotic susceptibility as a taxonomic characteristic of the genus Bacillus. Int. J. Syst. Bacteriol., 45, 40911.

Rintala, H., Pitkaranta, M., Toivola, M., Paulin, L. and Nevalainen, A. (2008), Diversity and seasonal dynamics of bacterial community in indoor environment. BMC Microbiol., 8, 56.

Romero, D., de Vicente, A., Olmos, J. L., Davila, J. C. and Perez-Garcia, A. (2007), Effect of lipopeptides of antagonistic strains of Bacillus subtilis on the morphology and ultrastructure of the cucurbit fungal pathogen Podosphaera fusca. J. Appl. Microbiol., 103, 969-76.

Sanchez-Porro, C., Martin, S., Mellado, E. and Ventosa, A. (2003), Diversity of moderately halophilic bacteria producing extracellular hydrolytic enzymes. J. Appl. Microbiol., 94, 295-300.

Souza, V.R., Silva, A.C.G. Pinotti, L.M., Araújo, H.S.S., Giordano, R.L.C.C.. Characterization of the penicillin $\mathrm{G}$ acylase from Bacillus megaterium ATCC 14945. Braz. arch. biol. technol., 48,105-111.
Stein, T. (2005), Bacillus subtilis antibiotics: structures, syntheses and specific functions. Mol. Microbiol., 56, 845-57.

van der Wal, F. J., Luirink, J. and Oudega, B. (1995), Bacteriocin release proteins: mode of action, structure, and biotechnological application. FEMS Microbiol. Rev., 17, 381-99.

Walker, R., Powell, A. A. and Seddon, B. (1998), Bacillus isolates from the spermosphere of peas and dwarf French beans with antifungal activity against Botrytis cinerea and Pythium species. J. Appl. Microbiol., 84, 791-801.

Wang, Q., Garrity, G. M., Tiedje, J. M. and Cole, J. R. (2007), Naive Bayesian classifier for rapid assignment of rRNA sequences into the new bacterial taxonomy. Appl. Environ. Microbiol., 73, 5261-7.

Whipps, J. M. (1997), Developments in the biological control of soil-borne plant pathogens. Adv. Botan. Res., 26, 1-134.

Whipps, J. M. (2001), Microbial interactions and biocontrol in the rhizosphere. J. Exp. Bot., 52, 487511.

Winn, W. J., Allen, S., Janda, W., Koneman, E., Procop, G. and Schreckenberger, P. (2006), Koneman's Color Atlas and WoodTextbook of Diagnostic Microbiology, 6th ed. Lippincott Williams and Wilkins, pp1736. 